\title{
FORMULATION AND QUALITY EVALUATION OF PEARL OYSTER MUSHROOM SOUP POWDER SUPPLEMENT WITH SOME KINDS OF LEGUMES AND VEGETABLES
}

\author{
Thuy Minh Nguyen ${ }^{1 凶}$, Keomixay Phoukham ${ }^{1,2}$, Tai Van $\mathrm{Ngo}^{1}$ \\ 1'Department of Food Technology, College of Agriculture, Can Tho University \\ 3/2 street, Xuan Khanh Ward, Ninh Kieu district, Can Tho city, Vietnam \\ ${ }^{2}$ Faculty of Food Science, Savannakhet University \\ Nonsavath village, Kaisonephomvihan city, Savannakhet, Laos
}

\begin{abstract}
Background. Soup could be used as an alternative to a meal as many of its nutrients could potentially fulfill the body's nutritional requirements. It is very practical and only takes a short time to prepare. In this study, the usefulness of supplementing dried vegetable soup mixtures with mushrooms and other vegetables to enhance its nutritional value was observed.

Material and methods. This study was carried out in order to develop a mixed soup powder supplemented with pearl oyster mushrooms, some legumes, and other vegetables. Eight formulas were prepared using different variations. Freeze-drying was used for pearl oyster mushroom and conventional drying (hot air) was applied for the other vegetables. The methods of Check-All-That-Apply (CATA) and Quantitative Descriptive Analysis (QDA) were applied for sensory evaluation and analysis.

Results. Out of the eight formulas of soup which were prepared, formula 8 resulted in a high-quality product with the highest acceptability. The total energy content was $459.14 \mathrm{kcal} / 100 \mathrm{~g}$ along with the Acceptable Macronutrient Distribution Ranges for protein $(25.73 \%)$, carbohydrates $(53.53 \%)$ and lipid $(20.74 \%)$. Sensory evaluation and product likelihood was also recorded.

Conclusion. The present study demonstrated that vegetable soup could be suitable for vegetarians and others due to its high and balanced nutritional values. Further studies are required to evaluate the nutritional composition of oyster pearl mushroom soup mixtures on a larger number of samples to ensure the accuracy of the nutritional contents presented.
\end{abstract}

Keywords: formulation, vegetable soup, physico-chemical, quality, sensory evaluation

\section{INTRODUCTION}

Vegetable-based soups are a great option nutritionally as they contain a high nutrient density with low energy. These products can provide a good quantity of important nutrients including vitamins and minerals, whilst containing relatively low calories. Some previous studies have indicated that a higher intake of vegetables may be associated with a reduction of cardiovascular diseases, obesity, diabetes, chronic respiratory diseases, and some types of cancer (Aune et al., 2017; Schwingshackl et al., 2015). However, the nutritional quality of vegetable soup could be improved by adding protein, mineral, and vitamin sources from 
the original plants which are suitable for vegetarians and others. Previous studies have indicated that the Pleurotus species are potent biological agents that convert unprepared organic products into palatable human food (Bermúdez et al., 2003). They are able to synthesize a greater proportion of essential amino acids, promote a positive balance of amino acids, and improve the overall taste. Mushrooms have antioxidant properties (Jayakumar et al., 2009), a low content of fat and sodium but a high potassium content (Sánchez, 2010). Furthermore, a limitation of plant proteins is their deficiency of amino acids. Therefore, mixing certain types of legumes, mushrooms, and vegetables could help to alleviate this problem (Upadhyay et al., 2017). Vegetables are a rich source of minerals and vitamins, dietary fibre, and a range of phytochemicals. Consequently, they would be a good choice for soup powder owing to their high nutritional quality. Legumes (green bean, black turtle bean, red kidney bean, and Dutch pea) and mushrooms have a high percentage of protein and a low amount of fat. Carrots and potatoes contain a relatively high amount of fiber, minerals, and vitamins. All these sources complement each other and make the dried soup an ideal healthy food for everyone. Moreover, in food processing, vegetables are dried to preserve them, their flavors, and their nutrients. Dried soup powders have the advantage of being protected from enzymatic alterations, oxidation, and loss of flavor. They are more stable due to the very low moisture content. However, there is still only limited data on the nutritional balance and sensory evaluation of dried vegetable soups. The objective of this study was to characterize newly formulated dried vegetables soups obtained from the blend of pearl oyster mushroom, certain kinds of legumes, and vegetables.

\section{MATERIAL AND METHODS}

\section{Raw materials and ingredients}

The raw materials used in this study included pearl oyster mushroom (Pleurotus ostreatus), pules green bean (Vigna radiata), Dutch pea (Pisum arvense sativum), red kidney bean (Phaseolus vulgaris), and black turtle bean (Phaseolus vulgaris). Other ingredients commonly used in vegetable soup include tomato, carrot, onion, garlic, white pepper, coriander, barley, potato, pumpkin, sugar, seasoning, and non-dairy creamer. All of them were purchased in Mega Market, Can Tho city, Vietnam.

\section{Preparation of raw materials}

The collected pearl oyster mushrooms were sorted and washed in tap water. However, the carrots, pumpkins, and tomatoes were sorted, washed, peeled and sliced in cubic form (carrot) and steamed in a microwave (SHARP R-G272VN, Thailand) for $5 \mathrm{~min}$ (high power at $800 \mathrm{~W}$ ). All materials being treated were dried in the hot air dryer $65^{\circ} \mathrm{C}$ for 7 hours (the moisture content of dried materials was about 6-7\%). After that, the dried samples were ground (except for carrot, which was in flake form) and sieved. The obtained powder was placed in sealed PE bags and stored at room temperature $\left(25^{\circ} \mathrm{C}\right)$ for further experiments. The process diagram for legumes is presented in Figure 1.

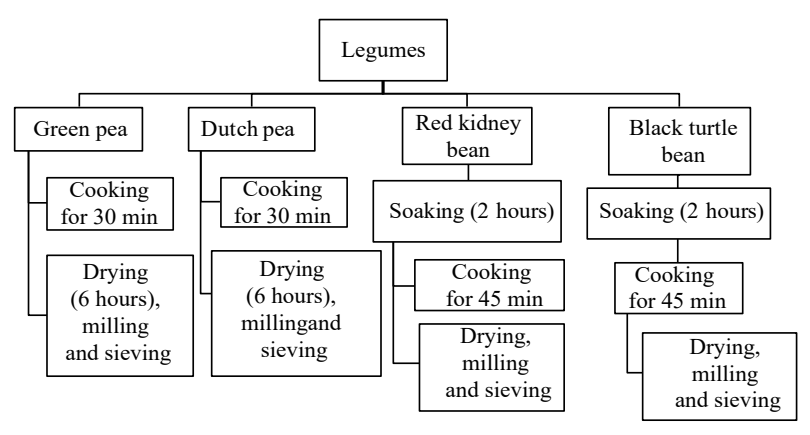

Fig. 1. Technological treatment for legumes before formulation

\section{Effect of freeze drying time on quality of pearl oyster mushroom}

$500 \mathrm{~g}$ of mushroom was dried in a freeze drier (ALPHA 2-4LD plus, Germany) at $-80^{\circ} \mathrm{C}$ under a pressure of $0.001 \mathrm{mBar}$ for $18-30$ hours. Next, the samples were characterized by determining their total phenolic content, moisture, protein, carbohydrate, lipid content, and color. Analysis was performed in triplicate. 
Nguyen, M. T., Phoukham, K., Ngo, V. T. (2020). Formulation and quality evaluation of pearl oyster mushroom soup powder supplement with some kinds of legumes and vegetables. Acta Sci. Pol. Technol. Aliment., 19(4), 435-443. http://dx.doi.org/10.17306/ J.AFS.2020.0813

Table 1. Formulation of the dried vegetarian soup powder, $\mathrm{g} / 100 \mathrm{~g}$

\begin{tabular}{lrrrrrrrr}
\hline \multirow{2}{*}{ Ingredients } & \multicolumn{1}{c}{ Formula } \\
\cline { 2 - 8 } & F1 & F2 & F3 & F4 & F5 & F6 & F7* & F8** \\
\hline Dried pearl oyster mushroom & 4 & 4 & 4 & 4 & 4 & 4 & 20 & 20 \\
Green bean & 4 & 20 & 4 & 4 & 4 & 8 & 4 & 4 \\
Red bean & 4 & 4 & 20 & 4 & 4 & 8 & 4 & 4 \\
Black bean & 4 & 4 & 4 & 20 & 4 & 8 & 4 & 4 \\
Dutch pea & 4 & 4 & 4 & 4 & 20 & 8 & 4 & 4 \\
Barley & 16 & 10 & 10 & 10 & 10 & 10 & 10 & 10 \\
Potato powder & 30 & 20 & 20 & 20 & 20 & 20 & 20 & 20 \\
\hline
\end{tabular}

*Hot-air dried mushroom.

**Freeze-dried mushroom.

\section{Preparation and formulation of dried vegetarian soup supplemented with mushroom, some legumes and others ingredients}

The composition of the eight formulated products is presented in Table 1.

The other ingredients used in the formula with a fixed content (Keomixay et al., 2019; g/100 g) include: tomato (3.8), pumpkin (3.2), carrot (3.8), garlic (0.5), onion (1), seasoning (5.1), sugar (1.8), coriander (0.2), white pepper $(0.2)$, non-dairy creamer (12), and full cream milk powder (2.4). The obtained formulae were used for physico-chemical and sensory analysis.

\section{Quality analysis}

The composition of the soup, such as the total carbohydrate, protein, moisture, fat, and crude fiber contents, was determined using the AOAC standard methods (AOAC, 2005). The determination of calcium, sodium and potassium was carried out by flame photometry (Arunkumar et al., 2015), using a FP6410 Flame Photometer. The cholesterol content was determined according to the method of Dinh et al. (2008). Vitamin C was determined using the Indophenol method (Zvaigzne et al., 2009). A SP-UV1000 Spectrophotometer $200 \sim 1000 \mathrm{~nm}$ was used to measure the absorbance at $450 \mathrm{~nm}$ in glass cuvettes for the total carotenoid analysis (Akbaraly et al., 2009). Total phenolic content was determined using the Folin-Ciocalteu reagent and was expressed as gallic acid equivalent (Ainsworth and Gillespie, 2007).

\section{Physical properties analysis}

The external color $\left(L^{*}, a^{*}\right.$ and $\left.b^{*}\right)$ of the vegetarian soup powder was evaluated using a CR-400 Chroma Meter (Japan). The water activity $\left(a_{w}\right)$ was measured using Rotronic Hygro Palm HP23-AW-A-SET-40 (USA).

\section{Total calories (kcal)}

The total number of calories was calculated using the formula (Thompson and Manore, 2017): fat $(\mathrm{g}) \times 9+$ protein $\times 4+$ total carbohydrate $(\mathrm{g}) \times 4$.

\section{Scanning Electron Microscopy (SEM)}

Scanning Electron Microscopy - SEM was used to visualize the microstructure of the dried mushrooms. Freeze-dried materials were coated with gold. The specimens were then photographed using a SEM (JEOL model J550, Japan) operating at $15 \mathrm{kV}$ for various magnifications (750 and $850 \times$ ).

\section{Sensory evaluation}

Quantitative Descriptive Analysis (QDA) and Check-All-That-Apply (CATA) were applied for sensory evaluation. Twenty panelists took part in this investigation. The panelists were consumers and their average age was 22 years old. The questions for the CATA 
Nguyen, M. T., Phoukham, K., Ngo, V. T. (2020). Formulation and quality evaluation of pearl oyster mushroom soup powder supplement with some kinds of legumes and vegetables. Acta Sci. Pol. Technol. Aliment., 19(4), 435-443. http://dx.doi.org/10.17306/ J.AFS.2020.0813

Table 2. The attributes that describe the dried vegetables soup

\begin{tabular}{lccc}
\hline \multicolumn{1}{c}{ Aroma } & Taste & $\begin{array}{c}\text { Texture/ } \\
\text { mouth-feel }\end{array}$ & Appearance \\
\hline Cooked beans & sour & swallow ability & lightness \\
Onion & salty & amount of particle & darkness \\
Pepper & umami & oily mouth-feel & greenyellow \\
$\begin{array}{l}\text { Cooked } \\
\text { mushroom }\end{array}$ & sweet & & orange \\
Other aroma & bitter & & \\
\hline
\end{tabular}

were multiple choice, which is commonly used in marketing research, in order to reduce responses (Espitia-López et al., 2019). Data is recorded in a binary format ( 0 - attribute not ticked, 1 - attribute ticked). The evaluated sensory characteristics are presented in Table 2. Every attribute was ticked and the five-point hedonic-scale was applied to evaluate the sensory attributes. The questions consisted of a list of words where the panelists would select those attributes considered appropriate to describe the sample. Moreover, every product was rated for overall liking (9-point hedonic scale) by each consumer.

\section{Data analysis}

Data analysis was carried out using STATGRAPHICS Centurion XV (USA). The XLSTAT 2007 (StatPoint Technologies Inc., USA) was used for sensory data analysis. This analysis provided a graphic showing the differences and similarities between the samples and the characteristic attributes.

\section{RESULTS AND DISCUSSION}

\section{Effect of freeze-drying on quality attributes of pearl oyster mushroom}

The physical properties of pearl oyster mushoom The color. Color is one of the most critical attributes of freeze-dried food products. The results obtained showed that the lightness, $L^{*}$ of mushroom, increased with drying time and that the samples dried at 18 and 24 hours were darker than the samples which were dried for 30 hours. The average color values of dried mushroom for 18 and 30 hours were $81.3 \pm 0.38,-8.18$ $\pm 0.05,15.43 \pm 0.14$ and $85.43 \pm 0.07,-8.32 \pm 0.09,15.32$ \pm 0.26 , respectively for $L^{*}, a^{*}$ and $b^{*}$. At a constant temperature, when the drying time was increased from 18 to 30 hours, the mushroom color was brighter and had the highest $L$ value after 30 hours of drying $(85.43 \pm 0.07)$. Freeze drying is a low-temperature dehydration process that removes the ice by sublimation at a low pressure. The brown color formation was limited during lyophilization (Thuy et al., 2020). Recently, Argyropoulos et al. (2011) reported that the $L^{*}$ values of freeze-dried mushrooms slightly increased during drying.

The SEM of pearl oyster mushrooms. Freeze-dried samples had shrunken into a porous or honey comb like structure. The porous structure is formed during sublimation.

The dried mushrooms prepared by freeze drying showed smoother microstructures than the dried mushrooms under hot air drying (Fig. 2). By freeze-drying, the original dimensions of the product are maintained
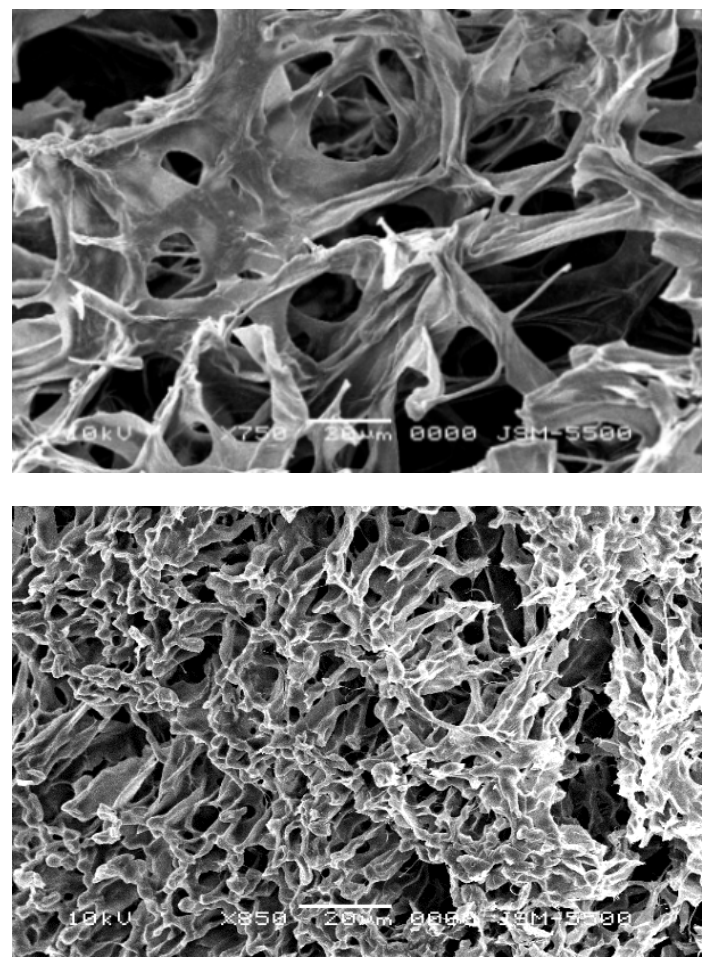

Fig. 2. Scanning electron microscopic (SEM) of hot air dried mushroom $(\times 750)$ at $65^{\circ} \mathrm{C}$ in $7 \mathrm{~h}$ (at the top) and freeze-dried mushroom $(\times 850)$ after $30 \mathrm{~h}($ bottom $)$ 
Nguyen, M. T., Phoukham, K., Ngo, V. T. (2020). Formulation and quality evaluation of pearl oyster mushroom soup powder supplement with some kinds of legumes and vegetables. Acta Sci. Pol. Technol. Aliment., 19(4), 435-443. http://dx.doi.org/10.17306/ J.AFS.2020.0813

Table 3. Effect of drying time on the chemical compounds of freeze-dried mushroom

\begin{tabular}{cccccc}
\hline $\begin{array}{c}\text { Drying time } \\
\mathrm{h}\end{array}$ & $\begin{array}{c}\text { Moisture content } \\
\%\end{array}$ & $\begin{array}{c}\text { Protein } \\
\%\end{array}$ & $\begin{array}{c}\text { Carbohydrate } \\
\%\end{array}$ & $\begin{array}{c}\text { Lipid } \\
\%\end{array}$ & $\begin{array}{c}\text { TPC } \\
\text { mg GAE/g }\end{array}$ \\
\hline 18 & $10.51^{\mathrm{c}}$ & $26.38^{\mathrm{a}}$ & $37.90^{\mathrm{a}}$ & $0.05^{\mathrm{a}}$ & $30.61^{\mathrm{a}}$ \\
24 & $5.24^{\mathrm{b}}$ & $31.73^{\mathrm{b}}$ & $47.13^{\mathrm{b}}$ & $0.06^{\mathrm{b}}$ & $30.92^{\mathrm{ab}}$ \\
30 & $3.00^{\mathrm{a}}$ & $31.98^{\mathrm{b}}$ & $52.88^{\mathrm{c}}$ & $0.07^{\mathrm{b}}$ & $31.14^{\mathrm{b}}$ \\
\hline
\end{tabular}

Values with different superscripts are significantly different $(P<0.05)$.

first by freezing. The ice is then sublimed under low pressure. Since there is no aqueous phase, there is no movement of water to the surface, only a receding interface of frozen and layer. The effects of shrinkage and water soluble components concentration, due to the mobility of the aqueous phase, are thereby prevented (Li-Shing-Tat and Jelen, 1987), and the resulting product is not shrunken but has small pores.

Chemical properties. Freeze-drying at a low temperature causes less deterioration in the chemical compositions of food products. It was observed that the nutritional position of the mushrooms after freezedrying at different times was significantly different $(p<0.05)$. The moisture content after 18 hours of drying was $10.51 \%$ and this reduced significantly to $5.24 \%$ and $3.00 \%$ respectively for 24 and 30 hours (Table 3 ).

An increase in nutrient contents was registered by increasing the drying time from 18 to 30 hours. The lowest nutrient contents of dried mushrooms were observed in the samples dried at 18 hours while the samples dried at 30 hours recorded the highest values of protein, carbohydrate, and lipid (31.98\%, 52.88\% and $0.069 \%$ ). These results are in agreement with those of Thuy et al. (2020) who showed that the protein and lipid content of freeze-dried chicken increased with drying time (12-48 hours).

During drying, heat and moisture transfers are coupled. It is a simultaneous heat and moisture transfer process where moisture is evaporated from the food material. In this process, water is eliminated by sublimation from a frozen state and the product temperature remains very low during the operation. Pearl oyster mushrooms are a rich source of nutrients and contain various bioactive compounds such as phenolic acids, flavonoids, ascorbic acid, glycosides, tocopherols, polysaccharides, ergthioeine and carotenoids (Gupta et al., 2017). The obtained results showed that the TPC of freeze-dried mushrooms was 30.607 and $31.137 \mathrm{mg}$ $\mathrm{GAE} / \mathrm{g}$ for 18 to 30 hours of drying, respectively. Minatel et al. (2017) reported that TPC in freeze-dried vegetables is better retained compared to the same samples when air-dried. In this case, freeze-drying could maintain the TPC of freeze-dried mushrooms at the drying time increased. Based on the obtained results, it was observed that this technique could become one of the most intriguing and feasible processes for drying food materials (Shofian et al., 2011).

\section{Formulation of the dried vegetarian soup mixtures Nutritional characteristic of the dried vegetable soup mixtures}

Oyster mushroom and legumes (green bean, red kidney bean, black turtle bean and Dutch pea) are good sources of protein, carbohydrates, and provide several essential minerals. The analysis results of the dried vegetarian soup quality are presented in Table 4 . The protein content of all formulas varied significantly $(p<0.05)$, in which the highest content was found in F4 $(25.6 \%)$. This may be due to the variety of legumes which were added and the freeze-dried mushrooms used, since the lower protein levels have been found in other formulations. The highest percentage of carbohydrate was about $65.98 \%$ in F1, which was higher than the other formulas. This is due to the high content of barley and potato powder which was added. The lipid content of the eight vegetable soup powders ranged from 8.55 to $9.20 \%$. The highest content was found in F6 (9.2\%), whereas the lowest amount was found in F3 (8.55\%).

The lipid content of the newly dried vegetable soup was higher than the results of previous studies (Rokhsana et al., 2007) but similar to the results of 
Nguyen, M. T., Phoukham, K., Ngo, V. T. (2020). Formulation and quality evaluation of pearl oyster mushroom soup powder supplement with some kinds of legumes and vegetables. Acta Sci. Pol. Technol. Aliment., 19(4), 435-443. http://dx.doi.org/10.17306/ J.AFS.2020.0813

Table 4. Nutritional characteristics of the dried vegetarian soup mixtures

\begin{tabular}{|c|c|c|c|c|c|c|c|}
\hline \multirow{2}{*}{ Formula } & \multicolumn{3}{|c|}{$\begin{array}{c}\text { Nutritional compositions } \\
\%\end{array}$} & \multirow{2}{*}{$\begin{array}{l}\text { Total energy } \\
\text { cals }\end{array}$} & \multicolumn{3}{|c|}{ Energy provided from macronutrients, $\%$} \\
\hline & protein & carbohydrate & lipid & & protein & carbohydrate & lipid \\
\hline $\mathrm{F} 1$ & $12.28^{\mathrm{a}}$ & $65.98^{\mathrm{g}}$ & $8.93^{\mathrm{d}}$ & $393.41^{\mathrm{g}}$ & $12.49^{\mathrm{a}}$ & $67.09^{\mathrm{g}}$ & $20.42^{\mathrm{ab}}$ \\
\hline $\mathrm{F} 2$ & $17.82^{\mathrm{b}}$ & $59.48^{\mathrm{f}}$ & $8.74^{\mathrm{b}}$ & $387.83^{\mathrm{f}}$ & $18.37^{\mathrm{b}}$ & $61.34^{\mathrm{f}}$ & $20.28^{\mathrm{b}}$ \\
\hline F3 & $22.39^{\mathrm{c}}$ & $56.12^{\mathrm{e}}$ & $8.55^{\mathrm{a}}$ & $390.95^{\mathrm{e}}$ & $22.90^{\mathrm{c}}$ & $57.42^{\mathrm{e}}$ & $19.68^{\mathrm{a}}$ \\
\hline F4 & $25.60^{\mathrm{g}}$ & $49.66^{\mathrm{b}}$ & $8.60^{\mathrm{ab}}$ & $378.46^{c}$ & $27.06^{\mathrm{h}}$ & $52.49^{\mathrm{b}}$ & $20.46^{\mathrm{ab}}$ \\
\hline F5 & $24.46^{\mathrm{f}}$ & $48.72^{\mathrm{a}}$ & $8.72^{\mathrm{b}}$ & $371.14^{\mathrm{a}}$ & $26.36^{\mathrm{g}}$ & $52.51^{\mathrm{b}}$ & $21.13^{\mathrm{c}}$ \\
\hline F6 & $24.19^{\mathrm{e}}$ & $48.75^{\mathrm{a}}$ & $9.20^{\mathrm{e}}$ & $374.56^{\mathrm{b}}$ & $25.83^{\mathrm{f}}$ & $52.06^{\mathrm{a}}$ & $22.11^{\mathrm{d}}$ \\
\hline F7 & $23.45^{\mathrm{d}}$ & $54.63^{\mathrm{d}}$ & $8.70^{\mathrm{b}}$ & $390.62^{\mathrm{e}}$ & $24.01^{\mathrm{d}}$ & $55.94^{\mathrm{d}}$ & $20.05^{b}$ \\
\hline F8 & $24.61^{\mathrm{f}}$ & $51.21^{\mathrm{c}}$ & $8.82^{\mathrm{c}}$ & $382.62^{\mathrm{d}}$ & $25.73^{e}$ & $53.53^{\mathrm{c}}$ & $20.74^{b}$ \\
\hline
\end{tabular}

Values with different superscripts are significantly different $(P<0.05)$.

Abdel-Haleem and Omran (2014) with the content ranging from 6.16 to $6.82 \%$. The total energy ( 371.14 to $393.41 \mathrm{Cals} / 100 \mathrm{~g}$ ) and percentage of energy provided from macronutrients were also calculated (as presented simultaneously in Table 4). The highest total energy was found in F1 (393.41 Cals/100 g), whereas the least was found in F5 (371.14 Cals/100 g). The lower energy value may be owing to lower fat, protein, and carbohydrate contents. The balance contained a macronutrients distribution which can help reduce the risk of disease and foster lasting weight loss. Acceptable macronutrient distribution ranges (AMDRs) for a particular energy source are associated with reducing the risk of chronic disease while providing intake of essential nutrients. AMDRs for adults (as a percentage of calories) are: protein $-10-35 \%$, fat $20-35 \%$, and carbohydrate $-45-65 \%$ (Thompson and Manore, 2017). The percentage of energy provided in dried vegetable soup (except F1) was acceptable with the AMDRs.

\section{Moisture content and water activity}

The highest and lowest moisture contents were recorded in F8 $(4.19 \pm 0.03 \%)$ and F4 $(6.88 \pm 0.03 \%)$, respectively. The other formulas have intermediate moisture contents between them. Mohajan et al. (2016) reported that the microorganisms couldn't grow when the moisture content was below $8 \%$. A moisture content less than $10 \%$ is considered more suitable for preventing quality degradation of the soup ingredients (Wakeel, 2007). The water activity $\left(a_{w}\right)$ of the products (eight formulas) showed significant difference, ranging from 0.209 to 0.235 . The highest and lowest water activity was recorded in F6 (0.235) and F8 (0.209), respectively. Microorganisms can grow at the minimum $a_{w}$ of 0.60 (Beuchat et al., 2013). The lowest $a_{w}$ for various food borne bacteria growth is about 0.87 , except for several halophilic bacteria which can grow at the lower $a_{w}$ of 0.75 . Lipid was seemed to have optimal stability and reduce oxidation rates at $a_{w}$ from 0.2 to 0.4 (Raitio et al., 2011).

\section{The color of the dried vegetable soup with some legumes}

The soup powder mixed with some legumes and mushrooms showed an increase in lightness. The $L^{*}$ values for F8 had the highest value (81.83; data not shown). It is clear that the use of freeze-dried mushrooms could improve the bright color of the soup after processing.

Sensory evaluation of dried vegetable soup mixtures. Dried soup should possess a desirable quality, representing the dominant flavor and aroma of the ingredients used. The sensory evaluation of the dried vegetable soup mixtures was assessed according to the quantitative descriptive analysis method. Reference standards for the sensory attributes were discussed 


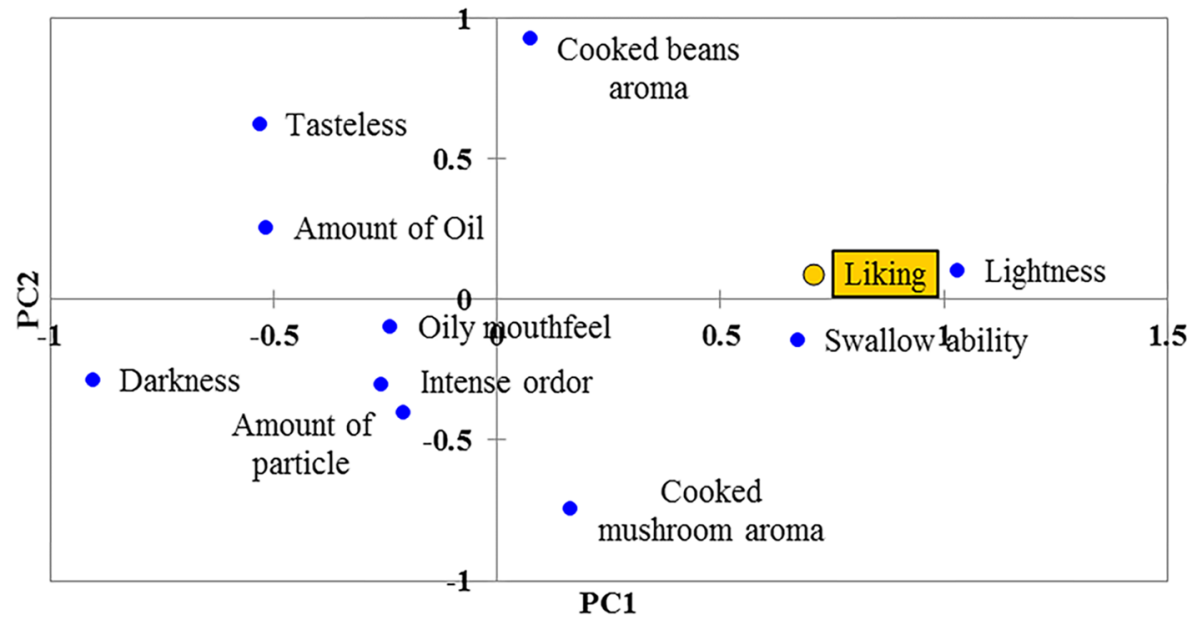

Fig. 3. Principal coordinate analysis (axes $\mathrm{PC}_{1}$ and $\mathrm{PC}_{2}$ ) of dried vegetable soup

among the panelists and applied upon consensus agreement in order to assist the panel in understanding each attribute in the same way. The descriptive analysis panel generated the attributes by describing the sensory characteristics of dried vegetable soup with mushroom and some legumes as well as determining their definitions for each term. There was a total of 19

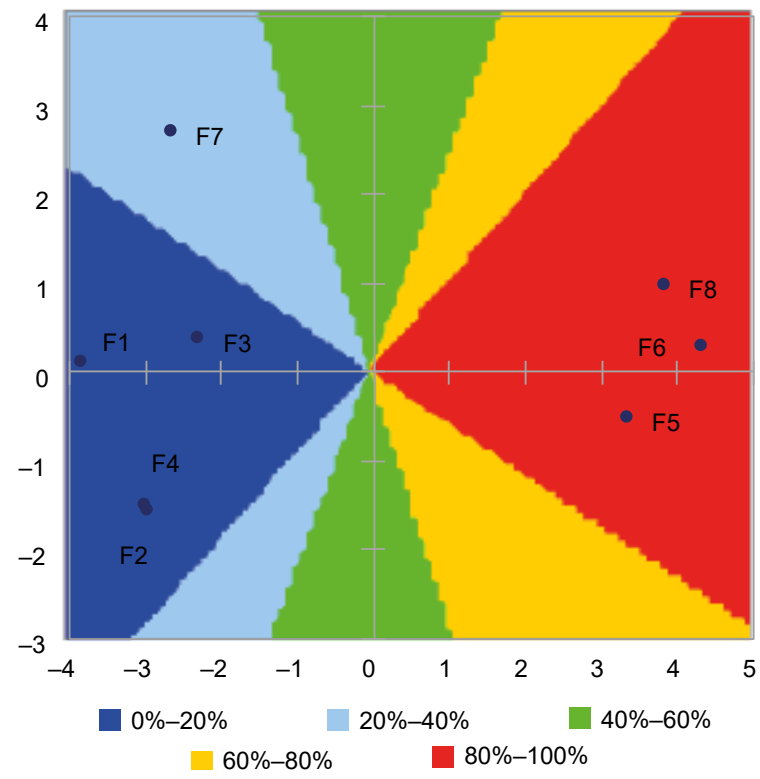

Fig. 4. Preference mapping of dried vegetable soup attributes classified into different categories in term of aroma, taste, texture/feel, and appearance (as shown in Table 2). The collected data was analyzed by CATA using XLSTAT software (Fig. 3) that represented the liking attributes of samples by panelists. It could be observed that the panelists preferred lightness in appearance, ease of swallowing, and texture attributes. Internal preference maps (Fig. 4) confirmed a higher acceptance level for the vegetable soup mixtures (F5, 6,8 ) over other formulas.

\section{Nutritional quality of selected soup formula}

Combining all the obtained results (physico-chemical, nutritional charateristic, and sensory properties), the dried vegetable soup with freeze-dried mushroom and some legumes of $\mathrm{F} 8$ proved to be the best formula (protein $24.61 \%$, carbohydrate $51.21 \%$ and lipid $8.82 \%$ ) with the lowest moisture content and water activity. The total energy of F8 was $382.62 \mathrm{Cals} / 100 \mathrm{~g}$, which was only slightly higher than the average value of all the formulas examined. The macronutrient content in F8 met the ranges for AMDR, with calories percentages from proteins, lipid, and carbohydrates at 25.73, 20.74 and $53.53 \%$, respectively. Nutritional claims have been restricted to those related to calories, protein, carbohydrates, fat, fiber, vitamins, and minerals. Some of the components have been analysed and identified as the limit, such as trans-fat, cholesterol, and sodium $(3.4 \mathrm{mg})$, indicating a nutritional product (Table 5). 
Nguyen, M. T., Phoukham, K., Ngo, V. T. (2020). Formulation and quality evaluation of pearl oyster mushroom soup powder supplement with some kinds of legumes and vegetables. Acta Sci. Pol. Technol. Aliment., 19(4), 435-443. http://dx.doi.org/10.17306/ J.AFS.2020.0813

Table 5. Nutritional quality of vegetable soup mixture (per 1 serving: $30 \mathrm{~g}$ )

\begin{tabular}{lrlllc}
\hline $\begin{array}{c}\text { Nutritional } \\
\text { compounds }\end{array}$ & Content & $\begin{array}{l}\text { Nutritional } \\
\text { compounds }\end{array}$ & Content & $\begin{array}{l}\text { Nutritional } \\
\text { compounds }\end{array}$ & Content \\
\hline Total fat & $2.65 \mathrm{~g}$ & calcium & $95.64 \mathrm{mg}$ & vitamin A & $36.38 \mathrm{mcg}$ \\
Total carbohydrate & $15.36 \mathrm{~g}$ & sodium & $16.23 \mathrm{mg}$ & fiber & $7.22 \mathrm{~g}$ \\
Protein & $7.38 \mathrm{~g}$ & potassium & $450.30 \mathrm{mg}$ & iron & $1.64 \mathrm{mg}$ \\
\hline
\end{tabular}

\section{CONCLUSION}

Freeze-drying eliminated moisture and tends to have less of an effect on mushroom quality than normal dehydration. This process could be used to store pearl oyster mushrooms, to extend shelf life, and for soup product preparation. From the analysis of physicochemical, nutritional characteristics, energy balance, and high acceptability, it could be demonstrated that F8 of dried vegetarian soup mixtures had reasonable amounts of the required nutrients and can be applied for a scale up in production.

\section{ACKNOWLEDGEMENTS}

We would like to express our gratitude to all those who gave us the possibility to complete this research. We would like to thank VLIR Network Vietnam Project for their support our study.

\section{REFERENCES}

Abdel-Haleem, A. M., Omran, A. A. (2014). Preparation of dried vegetarian soup supplemented with some legumes. Food Nutr. Sci., 5(22), 2274. https://doi.org/10.4236/ fns.2014.522241

Ainsworth, E. A., Gillespie, K. M. (2007). Estimation of total phenolic content and other oxidation substrates in plant tissues using Folin-Ciocalteu reagent. Nature Protoc., 2(4), 875-877. https://doi.org/10.1038/nprot.2007.102

Akbaraly, T. N., Favier, A., Berr, C. (2008). Total plasma carotenoids and mortality in the elderly: results of the Epidemiology of Vascular Ageing (EVA) study. British J. Nutr., 101(1), 86-92. https://doi.org/10.1017/ S0007114508998445

AOAC (2005). Official methods of analysis ( $18^{\text {th }}$ ed.). Washington DC: Association of Official Analytical Chemist.
Argyropoulos, D., Heindl, A., Müller, J. (2011). Assessment of convection, hot-air combined with microwavevacuum and freeze-drying methods for mushrooms with regard to product quality. Int. J. Food Sci. Technol., 46(2), 333-342. https://doi.org/10.1111/j.13652621.2010.02500.x

Arunkumar, D., Avinash, N. G., Rao, H., Robin, K. B., Samshuddin, S. (2015). Estimation of calcium, potassium and sodium contents in commonly consumed food of Karnataka coastal belt region, India. Pelagia Research Library. Chem. Sinica, 6(4), 100-103.

Aune, D., Giovannucci, E., Boffetta, P., Fadnes, L.T., Keum, N., Norat, T., ..., Tonstad, S. (2017). Fruit and vegetable intake and the risk of cardiovascular disease, total cancer and all-cause mortality-a systematic review and dose-response meta-analysis of prospective studies. Int. J. Epidem., 46, 1029-1056. https://doi.org/10.1093/ije/ dyw319

Bermúdez, R. C., Morris, Q. H., Danoso, F. C., Martínez, M. C., Ramos, S. E. (2003). Influencia de la luz en la calidad proteica de Pleurotus ostreatus var. Florida. Rev. Cuban. Invest. Bioméd., (22), 226-231.

Beuchat, L. R., Komitopoulou, E., Beckers, H., Betts, R. P., Bourdichon, F., Fanning, S., Ter Kuile, B. H. (2013). Low-water activity foods: increased concern as vehicles of foodborne pathogens. J. Food Prot., 76(1), 150-172. https://doi.org/10.4315/0362-028X.JFP-12-211

Dinh, T. T. N., Blanton Jr, J. R., Brooks, J. C., Miller, M. F., Thompson, L. D. (2008). A simplified method for cholesterol determination in meat and meat products. J. Food Comp. Anal., 21(4), 306-314.https://doi.org/10.1016/j. jfca.2008.02.001

Espitia-López, J., Rogelio-Flores, F., Angel-Cuapio, A., Flores-Chávez, B., Arce-Cervantes, O., ..., Garza-López, P. M. (2019). Characterization of sensory profile by the CATA method of Mexican coffee brew considering two preparation methods: espresso and French press. Int. J. Food Prop., 22(1), 967-973.

Gupta, K. K., Agarwal, S., Kushwaha, A., Maurya, S., Chaturvedi, V. K., Pathak, R. K., Singh, M. P. (2017). 
Nguyen, M. T., Phoukham, K., Ngo, V. T. (2020). Formulation and quality evaluation of pearl oyster mushroom soup powder supplement with some kinds of legumes and vegetables. Acta Sci. Pol. Technol. Aliment., 19(4), 435-443. http://dx.doi.org/10.17306/ J.AFS.2020.0813

Oyster mushroom: A rich source of antioxidants. In M. P. Singh, V. Verma, A. K. Singh (Eds.), Incredible world of biotechnology (pp. 43-57). Nova Science Publishers.

Jayakumar, T., Thomas, P. A., Geraldine, P. (2009). In-vitro antioxidant activities of an ethanolic extract of the oyster mushroom, Pleurotus ostreatus. Innov. Food Sci. Emer. Technol., 10(2), 228-234. https://doi.org/10.1016/j.ifset.2008.07.002

Keomixay, P., Nhu, T. T. H., Tai, N. V., Thuy, N. M. (2019). Effects of drying and grinding in production of healthy vegetarian soup mix. Int. J. Adv. Agric. Sci. Technol., 6(10), 29-39.

Li-Shing-Tat, B., Jelen, P. (1987). The microstructure and rehydration properties of the phoenix oyster mushroom (Pleurotus sajor caju) dried by three alternative processes. Food Struct., 6, 2, 135-142.

Minatel, I. O., Borges, C. V., Ferreira, M. I., Gomez, H. A. G., Chen, C. Y. O., Lima, G. P. P. (2017). Phenolic compounds: Functional properties, impact of processing and bioavailability. In M. Soto-Hernandez, M. PalmaTenango, M. del Rosario Garcia-Mateos (Eds.), Phenolic compounds - biological activity. IntechOpen. http:// dx.doi.org/10.5772/66368

Mohajan, S., Hossain, M., Farzana, T., Saha, T. (2016). Development of a healthy soup powder using phytonutrient enriched mushroom-moringa leaf. J. Allied Health Sci., 3(1), 33-40.

Raitio, R., Orlien, V., Skibsted, L. H. (2011). Storage stability of cauliflower soup powder: The effect of lipid oxidation and protein degradation reactions. Food Chem., 128(2), 371-379. https://doi.org/10.1016/j.foodchem.2011.03.038

Rokhsana, F., Yeasmin, R., Nahar, A. (2007). Studies on the development and storage stability of legume and vegetable based soup powder. Bangladesh J. Agric. Res., 32(3), 451-459. https://doi.org/10.3329/bjar.v32i3.547
Sánchez, C. (2010). Cultivation of Pleurotusostreatus and other edible mushrooms. Appl. Microbiol. Biotechn., 85(5), 1321-1337. https://doi.org/10.1007/s00253-0092343-7

Schwingshackl, L., Hoffmann, G., Kalle-Uhlmann, T., Arregui, M., Buijsse, B., Boeing, H. (2015). Fruit and vegetable consumption and changes in anthropometric variables in adult populations: A Systematic review and Meta-analysis of prospective cohort studies. PLoS ONE, 10, e0140846. https://doi.org/10.1371/journal. pone. 0140846

Shofian, N. M., Hamid, A. A., Osman, A., Saari, N., Anwar, F., Pak Dek, M. S., Hairuddin, M. R. (2011). Effect of freeze-drying on the antioxidant compounds and antioxidant activity of selected tropical fruits. Int. J. Mol. Sci., 12(7), 4678-4692. https://doi.org/10.3390/ ijms 12074678

Thompson, J., Manore, M. (2017). Nutrition: An applied approach $\left(5^{\text {th }}\right.$ ed $)$. New York: Pearson.

Thuy, N. M., Hang, L. T., Triep, T. L., Tan, N. D., Tai, N. V. (2020). Development and nutritional analysis of healthy chicken soup supplemented with vegetables in Viet Nam. Food Res., 4(1), 113-120. https://doi. org/10.26656/fr.2017.4(1).248

Upadhyay, S., Tiwari, R., Kumar, S., Kohli, D. (2017). Production and evaluation of instant herbal mix soup. Int. J. Agric. Sci. Res., 7, 37-42.

Zvaigzne, G., Karklina, D., Seglina, D., Krasnova, I. (2009). Antioxidants in various citrus fruit juices. Chem. Technol., 3(52), 56-61.

Wakeel, E. M. A. (2007). Ultra structure and functional properties of some dry mixes of food. Doctoral dissertation, M. Sc. Thesis, Faculty of Agriculture, Ain Shams University, Cairo. 